Mathematics in Philosophy 



\title{
Mathematics in Philosophy
}

\author{
SELECTED ESSAYS
}

\section{CHARLES PARSONS}

Cornell University Press

ITHACA, NEW YORK 
Cornell University Press gratefully acknowledges a grant from the Andrew W. Mellon Foundation that aided in bringing this book to publication.

\section{Copyright $\odot 1983$ by Cornell University Press}

All rights reserved. Except for brief quotations in a review, this book, or parts thereof, must not be reproduced in any form without permission in writing from the publisher. For information, address Cornell University Press, Sage House, 512 East State Street, Ithaca, New York 14850.

First published 1983 by Cornell University Press.

Published in the United Kingdom by Cornell University Press, Ltd., London.

First printing, Cornell paperbacks, 2005.

Printed in the United States of America

Library of Congress Cataloging in Publication Data

Parsons, Charles, 1933-

Mathematics in philosophy.

Bibliography: $\mathbf{p}$.

Includes index.

1. Mathematics-Philosophy-Addresses, essays, lectures. I. Title.

QA8.6.P37 $1983 \quad 5^{10^{\prime} .1} \quad 83-45^{153}$

ISBN-13: 978-o-8o14-8981-5 (pbk.: alk. paper)

ISBN-10: 0-8014-8981-4 (pbk.: alk. paper)

Cornell University Press strives to use environmentally responsible suppliers and materials to the fullest extent possible in the publishing of its books. Such materials include vegetable-based, low-VOC inks and acid-free papers that are recycled, totally chlorine-free, or partly composed of nonwood fibers. For further information, visit our website at www.cornellpress.cornell.edu.

$$
\text { Paperback printing } \quad 1098765432
$$


To the memory of my father 
